\title{
GAME OF NAMES IN BAROQUE POETRY
}

\author{
Iryna HAVRYLIUK
}

\section{Teacher at the Department of Theory and Practice of Romance and Germanic Languages, Makarenko Sumy State Pedagogical University, Ukraine orysia.bdzhilka@gmail.com}

\author{
ABSTRACT
}

Keywords: proper name, poetonym, baroque, postmodernism, game, poetry.

\section{ИГРА ИМЕН В ПОЭЗИИ БАРОККО}

The article is devoted to the problem of proper names use in baroque poetry. Using the examples drawn from the poetry written in two Indo-European languages belonging to different groups, we come to conclusions about functioning of names in the poetry of baroque epoch. Proper names, or poetonyms, which is a term designating proper names of a literary text, either form poetonym oppositions being a part of antithesis characteristic to the literature of this literary movement, or they become a means of onymic play, i.e. names are used as an element of decoration, a part of a game with the reader, a stylistic device to make high genres more accessible to a wide public. Proper names in baroque poetry used in the second function make the baroque movement closer to the postmodernism, which is similarly characterized by domination of game.

\section{АННОТАЦИЯ}

\section{Ключевые слова: имя собственное, поэтоним, барокко, постмодернизм, игра, поэзия.}

Статья посвящена проблеме имен собственных в поэзии барокко. Используя примеры с поэзии, написанной на двух индоевропейских языках, принадлежащих к разным группам, мы приходим к выводу о функционировании имён в поэзии эпохи барокко. Имена собственные, или поэтонимы, - то есть собственные имена художественного текста, - иди формируют поэтонимную оппозицию, которая является частью антитезиса, характерного для дитературы этого дитературнохудожественного направления, иди становятся средством онимной игры: имена исподьзуются как элемент украшения, часть игры с читателем, стидистическое средство, благодаря которому высокие жанры становятся более доступными для широкой публики. Имена собственные в поэзии барокко, используемые во второй функции, приближают направление барокко к постмодернизму, который подобным образом характеризуется доминированием игры. 


\section{Introduction}

As some researchers argue, the culture, including literature, develops in the form of sinusoid curves. In particular, this idea is expressed by Dmytro Chyzhevsky, a Ukrainian scholar of Slavic literature and the literary baroque (Chyzhevsky). He regarded the development of literature movements as a wave-like structure, in Figure 1.

This model which is criticized by other literary scholars, in particular, by Professor Hrabovych (Hrabovych 500-542), still exists and is still taken into account in literary studies. It vividly expresses the idea that traits of a literary movement can reappear in another epoch hundreds of years later. The esthetic views of the postmodern age we are living in bear a striking resemblance to the ones typical to the era of baroque. This idea is not new and it was investigated by numerous scholars. Thus, understanding the esthetic principles of baroque literature is another step towards understanding the postmodern literary process.

The problem of proper names in a literary work is the main one we are studying in this article. It is widely recognized that a proper name changes its functions when used in a literary text: in addition to a nominative function, it performs a stylistic function as well. The interaction between the name and the context it is placed in can bring some new connotations to its semantics. There are different terms used to designate a proper name in a literary text. We choose to use the term poetonym suggested by Professor Kalinkin (Kalinkin 9) to designate proper names of a literary text referring to virtual referents. By a virtual referent we mean a character or an object existing within a text. Proper names of real people, historical personalities, real places, etc. mentioned in a literary text are still poetonyms as the images of these characters and personalities undergoes a creative reinterpretation by the author.

In this research it is aimed to study the role of proper names in the baroque poetry and to discover the game element in their use, thus, proving the similarity between baroque and postmodernism.

Literary texts used to reach the above mentioned aim are the poetic works of Mexican baroque writer Juana Ines de la Cruz and the poetry of Ukrainian baroque representative Ivan Velychkovsky. The author of the present research understands that this choice is quite unexpected and does not represent the whole literature of baroque, but the latter would be impossible due to the wide range of representatives of the movement. This choice is also justified by the active use of proper names in the poetry of the given authors. We do not set an aim to compare the national peculiarities of baroque, although that seems logical within this research, but to follow general tendencies of name usage in this cultural period.

\section{Poetonym Oppositions}

The presence / absence of oppositions is the main stylistic difference in the literatures of baroque and postmodernism. While baroque tradition involves the frequent use of antithesis, the oppositions of postmodern period are not that clear. The reason is that the postmodern thinking is based on the ideas of post-structuralism which presupposes the destruction of structure and, therefore, oppositions in the form we know. Oppositions in postmodern literature still exist, but they are blurred due to the fact that in postmodernism "everybody has his or her own truth." On the contrary, the baroque oppositions are bright and visible.

In this research we use the term poetonym opposition by which we mean the opposition of virtual referents (i.e. characters of a literary work) that is projected on the poetonyms. Poetonym oppositions serve as a means of connection between the components of poetonymosphere, or the closed system of proper names of a literary work.

The most vivid examples of poetonym oppositions in the poetry by Juana Ines de la Cruz are con-

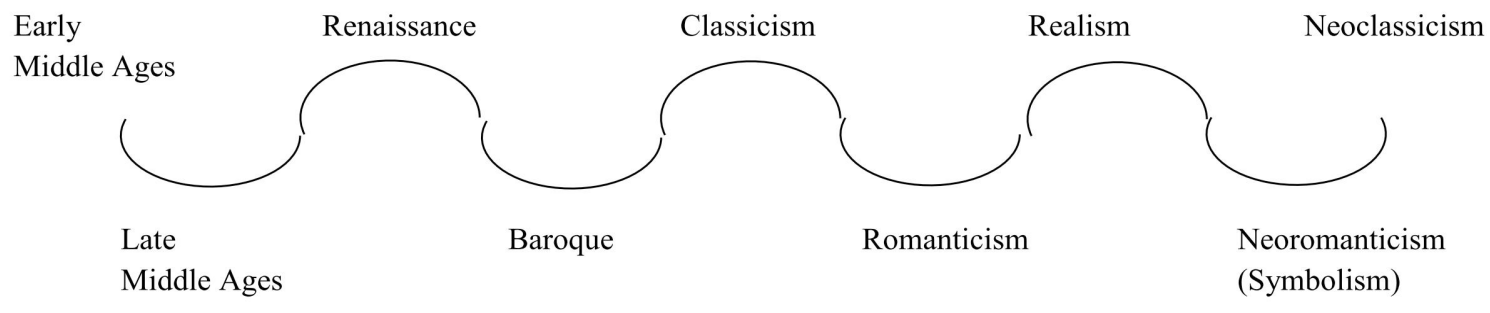

Figure 1. Sinusoid of literary movements (Chyzhevsky 355) 
tained in her sonnets about unrequited love:

Feliciano me adora y le aborrezco; Lysardo me aborrece y yo le adoro; por quien me apetece ingrato, lloro, $y$ al que me llora tierno no apetezco.

\section{("Correspondencias entre amar o aborrecer")}

Que no me quiera Fabio, al verse amado, es dolor, sin igual, en mi sentido, mas, que me quiera Silvio aborrecido es menos mal, mas no menor enfado.

("Resuelve la cuestión de cual sea pesar más molesto en encontradas correspondencias, amar o aborrecer")

The members of the mentioned oppositions $\mathrm{Fe}$ liciano - Lysardo, Fabio - Silvio have a similar phonetic structure: Feliciano - Lys $\underline{a}$ ardo, Fabio - Silvio, which makes them sound quite like poetonym oppositions-twins, or poetonym oppositions with a very similar phonetic and morphological structure, like Tweedledee - Tweedledum from "Through the Looking Glass" by Lewis Carroll. The fact that similar names are used as the components of antithesis underlines the absurdity of opposition.

Besides the typical names, which, as far as we know, do not allude to any well-known personalities, Juana Ines de la Cruz widely uses oppositions-allusions to mythology, biblical plots and real events. In her "Hombres necios que acusáis..." she uses the opposition Tais - Lucrecia, which stands for prostitute-virtuous woman.

\section{Queréis con presunción necia hallar a la que buscáis, para pretendida, Thais, y en la posesión, Lucrecia.}

We might have called this opposition purely contextual, as Lucrecia, whose name was adopted by the world literature as a synonym of virtue, and Thais, who was a hetaera, lived in different epochs and did not confront each other. But the poem of Sor Juana is not the exceptional one in which this oppositional pair is mentioned, e.g.: "Let her Lucrece all day be, Thaïs in the night to me, Be she such as neither will, Famish me, nor overfill" by Robert Herrick. We note the obvious difference in the tone of the authors of different sex living in the same period but belonging to different literary movements. The poem by Sor Juana sounds like a feminist response to the macho attitude of Robert Herrick, although they apply the same antithesis using the same poetonym op- position.

Another poetonym opposition, which is not contextual and which belongs to the so called precedential oppositions, is Pilatos - Cristo, the opposition evoked in the title of a sonnet "A la sentencia que contra Cristo dio Pilatos". This opposition was taken from the wellknown biblical plot, and its members correspond as $a$ victim of unfair judgment - an unfair judge. Actually, the study of the Bible deepens the multi-facet aspect of this opposition. The name of Pilate is associated with cruelty, hypocrisy, and inaction leading to a terrible crime. It is opposed to the name of Jesus Christ who, being the Savior of Humanity according to the Bible, is also agnus Dei (God's lamb) manifesting such characteristics as humility and obedience.

The poetry by Ivan Velychkovsky is equally marked by the presence of oppositions. The most evident one is between Eve and Mary, which is purely contextual, as the mentioned biblical figures were never opposed.

$$
\begin{gathered}
\text { Марія - Сва } \\
\text { Зі мною життя - не страх смерті. } \\
\text { мною жити, - не умерти. }
\end{gathered}
$$

The above mentioned poem is an example of an antithetical verse (carmen antitheticum), the both halves of which are placed in logical and formal opposition to one another. The opposition observed in Марія - Сва саn be best characterized by the scheme " $+=($ not -$)$ ". In this relation we find useful the study of Mahdi Shafieyan on binary oppositions and binary pairs in Quran (Shafieyan) and the article on the typology of poetonym opposition (Havryliuk).

Game approach to the introduction of names into text.

A special attention in baroque poetry was given to form, the aspect which is often neglected nowadays. Nevertheless, the strictness of form conditioned its playfulness. The wide use of acrostic was characteristic to baroque literature: 


\section{Soneto a Martín de Olivas}

Máquinas primas de su ingenio agudo

A Arquimedes, artifice famoso,

Raro nombre dieron de ingenioso;

¡Tanto el afán y tanto el arte pudo!

Invención rara, que en el mármol rudo

No sin arte grabó, maravilloso,

De su mano, su nombre prodigioso,

Entretejido en flores el escudo.

¡Oh! Así permita el Cielo que se entregue

Lince tal mi atención en imitarte,

I en el mar de la ciencia así se anegue

Vajel, que -al discurrir por alcanzarte-

Alcance que el que a ver la hechura llegue,

Sepa tu nombre del primor del Arte.

(Juana Inés de la Cruz)

\section{АКРОСТИХІС}

$\epsilon$ вірш, котрий краєграненням, тобто початковими літерами, імення МАРІЯ зображає, а до того ілітери,

що значать, назвою своєю подаються.

Мисліте, думку майте, але годі знати, Аз, Діва, як зуміла Господа зачати? Рци, тільки віру мавши, всяк християнине, Іже все знаєш, Боже, знаєш ти єдино, Аз, чиста і єдина, Діва, ношу сина. Ivan Velychkovsky)
Besides the traditional acrostics like that mentioned above devoted to the Virgin Mary, Ivan Velychkovsky widely used other ways to enter the name of his favorite biblical figure in the text, in particular by changing the order of syllables in the name and introducing thus obtained combination into the text of the poem:

\section{МАРІЯ}

\section{I МЯ PA}

Ім’я ра́дості твоє $\epsilon$, царице,

I МЯ РАдості наповни, Дівице.

The poem cited below is an example of encoding of numerous names intersecting each other. This is the way the author plays with a reader.

\section{ПЕРЕСІЧНИЙ}

$\epsilon$ вірш, який, одні імена пересікши, інші імена посередині їхній уміщує.

НеМАло Із неСУщих Створив ці твоРІннЯ, ДаДІм ХеРувИмСькую ТОму піСнь хВАління.

МАю Миру дАТИ Радість I наДІлюВАти слАдість.

Ivan Velychkovky's game of names was reflected in numerous labyrinths formed by names of Jesus and Virgin Mary:

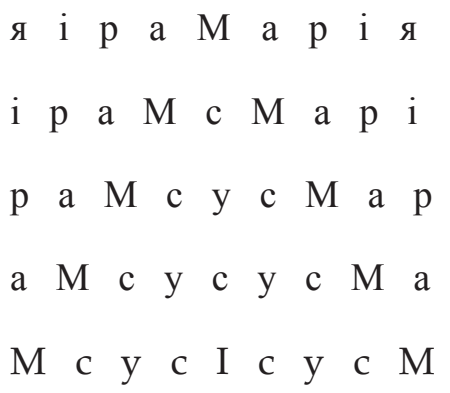

a $M$ c y c y c

p a $M$ c y c $M$ a $p$

i $p$ a $M$ c $M$ a $p$ i

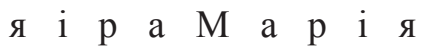


Despite its religious orientation, the use of a labyrinth is very secular due to its element of game. The labyrinth is one of the key notions of postmodernism, its image-metaphor. However, the symbolism of labyrinth was used in the baroque epoch long before the postmodern age (e.g. Amor es más laberinto of Juana Ines de la Cruz) and it could be defined as a baroque embodiment as well.

Transitions of the two names encoded in the given labyrinth might symbolize the birth Virgin Mary gave to Jesus Christ. Still these names form a poetonym opposition, which, if we follow the logics of Professor Shafieyan, can be called hierarchy (Shafieyan 198).

In the palindrome verses (or as he calls them "literary crayfish") by Ivan Velychkovsky, the use of a proper name is merely conditioned by its form. Thus, a name-palindrome Anna does not carry any special meaning, although it serves the phonetic purposes, forming alliterations and assonances:

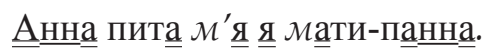

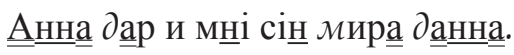

$\underline{\text { A}} \underline{\underline{H}} \underline{\underline{a}}$ мі $\mathcal{M} \underline{\underline{a}}$ ти і $m \underline{\underline{a}}$ мі $\mathcal{M} \underline{\underline{a}} \underline{\underline{H}} \underline{\underline{a}}$.

The manifestation of name games in the poetry by Juana Ines de la Cruz is quite different from the one we observed in the poetry by Ivan Velychkovsky. We are not going to dwell upon the differences of cultural, social and political situation of Mexico and Ukraine of that period. The reason of the distinct approach to literary expression might be hidden not only in the mentioned differences, but in the character of the authors. The rebellious character of Juana Ines de la Cruz prompted her to create poetry which would seem daring even in the postmodern age.

Sor Juana created a cycle of five sonnets written in colloquial speech, which in itself is a rebellious act towards a classical form of a sonnet, not mentioning the fact that their meaning was not less rebellious. The special feature of these sonnets was a wide use of nicknames - appellatives used in the function of proper names. By the capitalization of nouns and sometimes verbs, the author reaches the effect of colloquial language in which these nicknames were used by people of that time. The phonetic composition of the poetonyms makes them perfect in the sense of rhyming and forming the sound canvas of the sonnet.
Inés, cuando te riñen por Bellaca, para disculpas, no te falta Achaque porque dices, que traque, y que Barraque con que sabes muy bien tapar la Caca.

Si coges la palabra, no hay Urraca, que así la gorja de mal año Saques y con tronidos, más que un triqui Traque, a todo el Mundo aturdes, cual Matraca.

\section{Este bullicio todo lo Trabuca, este embeleco todo lo Embeleca, más, aunque eres (Inés) tan mala Cuca,}

sabe mi amor muy bien lo que se Peca, y así con tu afición no se Embabuca, aunque eres Zancarrón, y yo de Meca.

The similar approach to the use of capital letters can be traced in the prose of Ukrainian postmodern author Yuriy Andrukhovych: "То були Ангели Божі, Цигани, Маври, Козаки, Ведмеді, Спудеї, Чорти, Відьми, Русалки, Пророки, Отизі Васихіани в чорному, Жиди, Пігмеї, Повї, Улани, Легіонери, Пастушки, Ягнята, Каліки, Божевільні, Прокажені, Парахітики на Роздорожжу, Вбивиі, Розбишаки, Турки, Індуси, Січові Стрільці, Волоияюги, Кобзарі, Метахісти, Самураї, Дармограї <...>". Actually, the absurd enumeration is one of the features of a postmodern text, which serves to create the comicality. Nevertheless, the capitalization is not that common.

The mentioned kind of capitalization differs significantly from the one used by Sor Juana illustrated here: ¿En perseguirme, Mundo, qué interesas?; Aunque es clara del Cielo la luz pura / clara la Luna, y claras las Estrellas $<\ldots>$; Señora Doña Rosa, hermosa amago / de cuantas flores miren Sol y Luna $<\ldots$. ; Verde embeleso de la vida humana, I loca Esperanza, frenesi dorado <...>. In this case the capitalization serves as a means of personification and / or of grandiloquence.

One of the distinctive features of postmodern literature is author's self-reference, a tendency to self-consciousness, which can be vividly traced in the poetry of Ivan Velychkovsky and Juana Ines de la Cruz. One of the manifestations of this self-consciousness and re- 
flexivity is mentioning the author's name in his / her texts. Sor Juana frequently addresses herself (as the cited above sonnet proves) in her poetry. Thus, the author and her creation enter an endless Ouroboros, a closed cycle of allusions. The same can be said about the poetry of Ivan Velychkovsky, but he complicates the game with the reader encoding his name into the text: In the first cited verse, Ivan Velychkovsky encoded his name twice in the right order, in the second one his name is hidden in a palindromic way.

\section{ОСТАТНЯ ШТУЧКА}

Ісуса Христа ВЕЛИЧаймО,

КОтрий Вам СолодКИЙ, зНаймо

Із неВпізнАНого отця постав він чисто,

ВЕЛИЧаю з матКОю Вас, СолодКИЙ Христе.

\section{АВТОР ДО ЧИТАЛЬНИКА}

НАстрОЙ навспак цинобру. Коли угадаєш,

ГіршИЙ Котрий з Сих? ВОвК? ЧИ ЛЕВ? -

То мене пізнаєш.

\section{Conclusions.}

The use of proper names in baroque poetry is one of the ways to add expressiveness to the language, to make a reader enter a game played by an author. Generally, we can classify all usages of proper names into two:

1. The use within a poetonym opposition, usually of allusive nature (which, actually, means a kind of game connected with deciphering an allusion). The oppositions of baroque poetry are better outlined and much more vivid than those of postmodernism.

2. The game-like use proper to postmodern texts: use of names as elements of form, use of phonetically similar appellatives in the form of proper names; self-reference with the use of proper names, etc. The playfulness of baroque differentiates it from the parallel movement - classicism with its strictness of form and meaning. Baroque authors tend to express serious ideas using frivolous but still very sophisticated forms.

This research does not claim to be complete, and is rather an overview of general tendencies of proper name usage in the baroque poetry. The further research is will provide a more detailed picture of proper names usage in a certain national literature.

\section{References:}

Chyzhevsky, Dmytro. Ukrayins'ke literaturne baroko (Ukrainian literary baroque). 2003. Web. $16 \mathrm{Au-}$ gust 2017.

Havryliuk, Iryna. Typolohiya poetonimnoyi opozytsiyi (Typology of poetonym opposition) Zapysky z onomastyky (Records in onomastics) 18 (2015): 128135.Print.

Hrabovych, Hryhoriy. Do istoriyi ukrayins'koyi literatury: doslidzhennya, ese, polemika (To the History of Ukrainian Literature: researches, essays, polemics). Kyiv: Osnovy, 1997. Print.

Kalinkin, Valeriy. Teoretychni osnovy poetonimnoyi onomastyky (Fundamental theory of poetic onomastics). Diss. Taras Shevchenko Kyiv National University, Kyiv, 2000. Print.

Shafieyan, Mahdi. Binary Oppositions and Binary Pairs. From Derrida to the Islamic Philosophy. 2011 $2^{\text {nd }}$ International Conference on Humanities and Social Sciences IPEDR 17 (2011): 195-199. Print. 